\title{
Article
}

\section{Reverse Ordered Sequential Mechanism for Lactoperoxidase with Inhibition by Hydrogen Peroxide}

\author{
Kellye Cupp-Sutton and Michael T. Ashby * \\ Department of Chemistry and Biochemistry, University of Oklahoma, Norman, OK 73019, USA; \\ kellye.a.cupp-1@ou.edu \\ * Correspondence: mashby@ou.edu
}

check for updates

Citation: Cupp-Sutton, K.; Ashby, M.T. Reverse Ordered Sequential Mechanism for Lactoperoxidase with Inhibition by Hydrogen Peroxide. Antioxidants 2021, 10, 1646. https:// doi.org/10.3390/antiox10111646

Academic Editors: Jürgen Arnhold and Ernst Malle

Received: 7 August 2021

Accepted: 4 October 2021

Published: 20 October 2021

Publisher's Note: MDPI stays neutral with regard to jurisdictional claims in published maps and institutional affiliations.

Copyright: (c) 2021 by the authors. Licensee MDPI, Basel, Switzerland. This article is an open access article distributed under the terms and conditions of the Creative Commons Attribution (CC BY) license (https:/ / creativecommons.org/licenses/by/ $4.0 /)$.

\begin{abstract}
Lactoperoxidase (LPO, Fe ${ }^{\mathrm{III}}$ in its resting state in the absence of substrates) —an enzyme secreted from human mammary, salivary, and other mucosal glands-catalyzes the oxidation of thiocyanate $\left(\mathrm{SCN}^{-}\right)$by hydrogen peroxide $\left(\mathrm{H}_{2} \mathrm{O}_{2}\right)$ to produce hypothiocyanite $\left(\mathrm{OSCN}^{-}\right)$, which functions as an antimicrobial agent. The accepted catalytic mechanism, called the halogen cycle, comprises a two-electron oxidation of LPO by $\mathrm{H}_{2} \mathrm{O}_{2}$ to produce oxoiron(IV) radicals, followed by $\mathrm{O}$-atom transfer to $\mathrm{SCN}^{-}$. However, the mechanism does not explain biphasic kinetics and inhibition by $\mathrm{H}_{2} \mathrm{O}_{2}$ at low concentration of reducing substrate, conditions that may be biologically relevant. We propose an ordered sequential mechanism in which the order of substrate binding is reversed, first $\mathrm{SCN}^{-}$and then $\mathrm{H}_{2} \mathrm{O}_{2}$. The sequence of substrate binding that is described by the halogen cycle mechanism is actually inhibitory.
\end{abstract}

Keywords: lactoperoxidase; thiocyanate; kinetics; mechanism

\section{Introduction}

Secretory proteins play essential roles in human host defense. Perhaps the most widely studied secretory protein is lactoperoxidase (LPO, EC 1.11.1.7) [1]. LPO is a heme oxidoreductase ( $\mathrm{Fe}^{\mathrm{III}}$ in its resting state) that catalyzes the oxidation of a variety of substrates by hydrogen peroxide $\left(\mathrm{H}_{2} \mathrm{O}_{2}\right)$. The accepted catalytic mechanism, a two-electron oxidation of native LPO-[Fe $\left.{ }^{\mathrm{III}}\right]$ (Figure 1A, Equation (1)) followed by O-atom transfer from the enzyme to the substrate (Figure 1A, Equation (2)), is often referred to as the "halogen cycle". The intermediate enzyme species, Compound I, is an oxoiron (IV) radical, with the organic radical located on the porphyrin ( $\left.\mathrm{Cpd} \mathrm{I-}\left[\mathrm{Fe}^{\mathrm{IV}}=\mathrm{O}, \pi^{+} \cdot\right]\right)$ [2]. According to this widely accepted mechanism, substrate selectivity is determined by the rate of the reaction of Cpd I with potential substrates [3], which in turn is a function of the rate constants for the second step of the halogen cycle mechanism and the concentrations of the substrates in various physiologic fluids [4]. Although iodide $\left(\mathrm{I}^{-}\right)$reacts with LPO with a significant rate constant, the pseudo-halide thiocyanate $\left(\mathrm{SCN}^{-}\right)$is generally more abundant in physiologic fluids, and it is believed to be the exclusive substrate of LPO in vivo. Thus, the antimicrobial activity of the LPO system is attributed to hypothiocyanite $\left(\mathrm{OSCN}^{-}\right)$[5]. 


\section{A. Halogen Cycle}

$$
\begin{aligned}
& \text { LPO-[Fe } \left.{ }^{I I I}\right]+\mathrm{H}_{2} \mathrm{O}_{2} \stackrel{\mathrm{K}_{1}}{\longrightarrow} \mathrm{CpdI}+\mathrm{H}_{2} \mathrm{O} \\
& \mathrm{Cpd} \mathrm{I}+\mathrm{X}^{-} \stackrel{\mathrm{K}_{2}}{\longrightarrow} \text { LPO-[Fe } \mathrm{LP}^{\text {III }]}+\mathrm{OX}^{-}
\end{aligned}
$$

\section{B. Reverse Ordered Sequential Mechanism}

$$
\begin{aligned}
& \text { Catalysis } \\
& \text { LPO-[Fe } \left.\mathrm{Fe}^{\prime \prime \prime}\right]+\mathrm{SCN}^{-} \underset{\mathrm{k}_{-3}}{\stackrel{\mathrm{k}_{3}}{\rightleftharpoons}} \text { LPO-SCN } \\
& \text { LPO-SCN }+\mathrm{H}_{2} \mathrm{O}_{2} \stackrel{\mathrm{k}_{4}}{\longrightarrow} \\
& \text { LPO-[Fe } \left.{ }^{l l l}\right]+\mathrm{OSCN}^{-}+\mathrm{H}_{2} \mathrm{O} \\
& \text { Inhibition } \\
& \text { LPO-[Fe } \left.{ }^{I I I}\right]+\mathrm{H}_{2} \mathrm{O}_{2} \underset{\mathrm{k}_{-5}}{\stackrel{\mathrm{k}_{5}}{\rightleftharpoons}} \text { LPO- } \mathrm{H}_{2} \mathrm{O}_{2}
\end{aligned}
$$

Figure 1. (A) The literature "Halogen Cycle" mechanism of the LPO-catalyzed oxidation of halides and pseudohalide. (B) Proposed (reverse) ordered sequential kinetic mechanism of the LPO-catalyzed oxidation of thiocyanate and inhibition by tight binding of hydrogen peroxide.

When the reaction of LPO-[Fe $\left.{ }^{\mathrm{III}}\right]$ with $\mathrm{H}_{2} \mathrm{O}_{2}$ is rate-limiting, as has been reported for $\mathrm{SCN}^{-}$[3], the kinetics of the halogen cycle mechanism are expected to be first-order in $\left[\mathrm{H}_{2} \mathrm{O}_{2}\right]$ and independent of reducing substrate concentration $\left(\left[\mathrm{X}^{-}\right]\right)$. This is what is observed at high concentration of $X=\mathrm{SCN}^{-}$(relative to the concentration of $\mathrm{H}_{2} \mathrm{O}_{2}$ ). However, we report here that the catalytic reaction becomes biphasic at a low concentration of reducing substrate (relative to $\mathrm{H}_{2} \mathrm{O}_{2}$ ), a first-order reaction followed by a zeroth-order reaction. A new mechanism is proposed that accounts for the kinetics under all reaction conditions-a reverse-ordered sequential mechanism where the initial reaction is the binding of LPO-[Fe$\left.{ }^{\mathrm{III}}\right]$ with $\mathrm{SCN}^{-}$(Figure $1 \mathrm{~B}$, Equation (3)), not $\mathrm{H}_{2} \mathrm{O}_{2}$, as described by the halogen cycle. The resulting bound LPO species (LPO-SCN) subsequently reacts with $\mathrm{H}_{2} \mathrm{O}_{2}$ irreversibly in the turnover-limiting step to produce native $\mathrm{LPO}-\left[\mathrm{Fe}^{\mathrm{III}}\right]$ and hypothiocyanite $\left(\mathrm{OSCN}^{-}\right)$(Figure 1B, Equation (4)). However, $\mathrm{H}_{2} \mathrm{O}_{2}$, in addition to acting as the oxidizing agent, also acts as a tight binding inhibitor of $\mathrm{LPO}-\left[\mathrm{Fe}^{\mathrm{III}}\right]$ to produce a LPO- $\mathrm{H}_{2} \mathrm{O}_{2}$ bound species which is inactive or less active in catalysis (Figure 1B, Equation (5)). Through time-resolved spectral deconvolution, we have identified the $\mathrm{LPO}-\mathrm{H}_{2} \mathrm{O}_{2}$ bound species as Compound $\mathrm{I}^{*}\left(\mathrm{Cpd} \mathrm{I}^{*}-\left[\mathrm{Fe}^{\mathrm{IV}}-\mathrm{OH}, \mathrm{aa}^{+} \cdot\right]\right.$, an oxoiron(IV) radical like $\mathrm{Cpd}$ I, albeit protonated [6-8], but with the organic radical relocated from the porphyrin to an amino acid). The possible biological significance of the new mechanism is discussed.

\section{Materials and Methods}

\subsection{Materials}

Water was doubly distilled in glass. The concentrations of $\mathrm{H}_{2} \mathrm{O}_{2}$ $\left(\varepsilon_{240 \mathrm{~nm}}=36.4 \mathrm{M}^{-1} \mathrm{~cm}^{-1}\right), \mathrm{LPO}\left(\varepsilon_{412 \mathrm{~nm}}=112,000 \mathrm{M}^{-1} \mathrm{~cm}^{-1}\right)$, and TNB (5-thio-2-nitrobenzoic acid, $\varepsilon_{412 \mathrm{~nm}}=14,150 \mathrm{M}^{-1} \mathrm{~cm}^{-1}$ ) were determined spectrophotometrically. Solutions of $\mathrm{NaSCN}$ and LPO were buffered in $100 \mathrm{mM} \mathrm{pH} 7$ phosphate (prepared using $\mathrm{NaH}_{2} \mathrm{PO}_{4}$, $\mathrm{Na}_{2} \mathrm{HPO}_{4}$, and $\mathrm{NaOH}$ ). Buffers were treated with Chelex-100. 


\subsection{Instruments}

pH was measured using an Orion Research Expandable ionAnalyzer EA 920. Absorbance measurements were made with an HP 8452A diode array spectrophotometer. Stopped-flow data were collected using a Hi-Tech SF-661 DX2 instrument (TgK Scientific Limited, Bradford-on-Avon, United Kingdom) equipped with a xenon arc lamp, a $1.00 \mathrm{~cm}$ path length quartz sample cell, and a photomultiplier tube for monochromatic detection or a diode array for collection of polychromatic data.

\subsection{Stopped-Flow Data}

Single mixing stopped-flow experiments according to the scheme in Figure $\mathrm{S} 1$ were used to probe the mechanism of the LPO-catalyzed oxidation of $\mathrm{SCN}^{-}$and $\mathrm{H}_{2} \mathrm{O}_{2}$. Experiments were done under what will be considered "high concentration" and "low concentration" of reducing substrates. High concentration of reducing substrates refers, in general, to experiments we conducted where $\left[\mathrm{SCN}^{-}\right] \geq 1 \mathrm{mM}$, [LPO] $\geq 1 \mu \mathrm{M}$, and pseudofirst-order conditions of $\left[\mathrm{SCN}^{-}\right]$with respect to $\left[\mathrm{H}_{2} \mathrm{O}_{2}\right]$ were used. Low concentration of reducing substrates refers, in general, to experiments conducted under conditions of $\left[\mathrm{SCN}^{-}\right] \leq 1 \mathrm{mM}$, stoichiometric or near stoichiometric conditions of $\left[\mathrm{SCN}^{-}\right]$with respect to $\left[\mathrm{H}_{2} \mathrm{O}_{2}\right]$, and $[\mathrm{LPO}] \leq 1 \mu \mathrm{M}$. High and low concentration conditions were optimized to observe the effects of varying reactant and enzyme concentrations where first-order and biphasic reaction trace kinetics were observed, respectively. Experimental traces were collected at $412 \mathrm{~nm}$ to observe the change in TNB during the LPO catalysis. Five runs were averaged and fit to a Mathematica model described in the Supplementary Materials. Data from the experiments where the biphasic reaction kinetics were observed were collected for the pre-steady-state reaction in-dependently to obtain more resolved traces. Data were then collected over the entire reaction time and the data sets were merged.

\subsection{Effect of Mixing Order}

The effect of the order of mixing was determined under low [SCN-] conditions. Two double mixing stopped-flow experiments were performed which first allowed LPO and $\mathrm{SCN}^{-}$to come to equilibrium in the first mixing cycle, then added $\mathrm{H}_{2} \mathrm{O}_{2}$ in the second mixing cycle to initiate catalysis. A second double mixing experiment reacted LPO with $\mathrm{H}_{2} \mathrm{O} 2$ in the first mixing cycle, then added $\mathrm{SCN}^{-}$in the second mixing cycle. The ageing time in both experiments was $1 \mathrm{~s}$. Schematics of the mixing schemes are summarized in Figure S2 (for data of Figure 3A) and Figure S3 (for data of Figure 3B).

\subsection{Data Analysis}

Monochromatic kinetic data was analyzed using Kinetic Studio Version 1.0.12.19577. Poly-chromatic kinetic data were deconvoluted and fit using SPECFIT Version 3.0.40. Leastsquares analysis to determine the relationship between observed rate constants was carried out using KaleidaGraph Version 3.5. Mathematica was used to model the kinetic data and to perform nonlinear fits to determine the rate constants. The code for the Mathematica model and additional details regarding data analysis are available in the Supplementary Text.

\section{Results and Discussion}

While the results and discussions are comingled, we have carefully separated our observations from interpretation. For example, kinetics and the rate law only suggest the chemical composition of the species involved, and not their structures. Accordingly, after a model is presented that describes the kinetics, we discuss the possible structures of species in the context of extra-kinetic data and the literature. Note the rate law provides insight into the turnover-limiting step of the catalytic cycle and the reversible steps that precede it; however, kinetics are silent in the subsequent steps of the catalytic cycle. Specifically, kinetics do not speak to the chemical nature of the species formed when LPO-SCN reacts with $\mathrm{H}_{2} \mathrm{O}_{2}$. 


\subsection{General Observations of Kinetics at High $\left[\mathrm{SCN}^{-}\right]$}

When $\left[\mathrm{SCN}^{-}\right] \geq 1 \mathrm{mM},[\mathrm{LPO}] \geq 1 \mu \mathrm{M}$, and pseudo-first-order conditions of $\left[\mathrm{SCN}^{-}\right]$ with respect to $\left[\mathrm{H}_{2} \mathrm{O}_{2}\right]$ are used, exponential kinetics are observed with first-order dependence on the $\left[\mathrm{H}_{2} \mathrm{O}_{2}\right]$ (Table S1) and first-order dependence on [LPO]. Slight systematic dependence on the $\left[\mathrm{SCN}^{-}\right]$is observed (Table S2). Accordingly, under conditions of high $\left[\mathrm{SCN}^{-}\right]$the experimental data essentially reflect the order dependencies predicted by the LPO halogen cycle model when the first step is rate-limiting (Figure 1A, Equation (1)).

\subsection{General Observations of Kinetics at Low $\left[\mathrm{SCN}^{-}\right]$}

The mechanism of Figure 1A does not predict any change in the kinetics under conditions of low $\left[\mathrm{SCN}^{-}\right]$, when $\mathrm{k}_{2}>\mathrm{k}_{1}$, unless $\left[\mathrm{H}_{2} \mathrm{O}_{2}\right]$ greatly exceeds $\left[\mathrm{SCN}^{-}\right]$. However, we observe biphasic kinetics with a first-order reaction followed by a zeroth-order reaction when $\left[\mathrm{SCN}^{-}\right]<1 \mathrm{mM}$, with stoichiometric or near stoichiometric $\left[\mathrm{SCN}^{-}\right]$with respect to $\left[\mathrm{H}_{2} \mathrm{O}_{2}\right]$, and [LPO] $\leq 1 \mu \mathrm{M}$ (e.g., Figure 2). Importantly, the first phase of the reaction is not a classic "burst phase", as more than one enzyme turn-over is involved. Additionally, under the conditions of our experiments, the $\left[\mathrm{SCN}^{-}\right]$remains constant throughout the reaction because of the stoichiometry of the assay (TNB is 2-nitro-5-thiobenzoic acid and DTNB is the corresponding disulfide):

$$
\begin{aligned}
& \mathrm{H}_{2} \mathrm{O}_{2}+\mathrm{SCN}^{-} \longrightarrow \mathrm{H}_{2} \mathrm{O}+\mathrm{OSCN}^{-}
\end{aligned}
$$

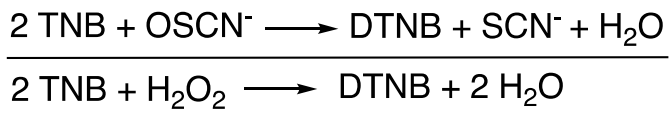

All of the experiments (except those that produce Figure 5) were carried out in the presence of TNB.

\subsection{Kinetics at Low $\left[\mathrm{SCN}^{-}\right]$as a Function of $\left[\mathrm{SCN}^{-}\right]$}

When the $\left[\mathrm{SCN}^{-}\right]$is relatively low, biphasic kinetics are observed with a first-order reaction followed by a zeroth-order reaction (Figure 2). However, as the $\left[\mathrm{SCN}^{-}\right]$is increased, the number of enzyme turnovers during the first phase of the reaction also increases (Figure $\mathrm{S} 4)$. When the $\left[\mathrm{SCN}^{-}\right]$becomes sufficiently high, the kinetics become strictly firstorder and the reaction rate became largely independent of $\left[\mathrm{SCN}^{-}\right]$(Figure 2D). When the pre-steady-state reaction is fit to a first-order model, the observed rate constant decreased with increasing $\left[\mathrm{SCN}^{-}\right]$(Figure S5). However, the dependence of the observed rate constant $\left(\mathrm{k}_{\mathrm{obs}}\right)$ on $\left[\mathrm{SCN}^{-}\right]$is not linear until at sufficiently high $\left[\mathrm{SCN}^{-}\right]$, when the rate of the reaction becomes independent of $\left[\mathrm{SCN}^{-}\right]$. It was first hypothesized that $\mathrm{SCN}^{-}$acts as an enzyme inhibitor; however, examination of initial reaction rates indicates that the reaction is independent of $\left[\mathrm{SCN}^{-}\right]$(Table S3). Instead, it appears that this initial reaction is a result of a pre-steady-state reaction, which is separate from the $\mathrm{SCN}^{-}$oxidation catalysis and is inhibited by $\mathrm{SCN}^{-}$.

In contrast to the pre-steady-state reaction, the number of enzyme turnovers which occur during the (steady-state) zeroth-order reaction decrease as $\left[\mathrm{SCN}^{-}\right]$is increased. The reason for the decrease in the number of enzyme turnovers that occur during the steadystate reaction is two-fold. First, as $\mathrm{H}_{2} \mathrm{O}_{2}$ is the limiting reagent, the ratio of $\mathrm{H}_{2} \mathrm{O}_{2}$ reacted in the pre-steady-state versus the steady-state reaction increases until the steady-state reaction is no longer observed. Second, the rate of the steady-state reaction exhibits first-order dependency on $\left[\mathrm{SCN}^{-}\right]$(Figure S6). This causes the two reactions to become less resolved and more difficult to distinguish, particularly at higher $\left[\mathrm{SCN}^{-}\right]$(e.g., traces $\mathrm{C}$ and $\mathrm{D}$ of Figure 2). 

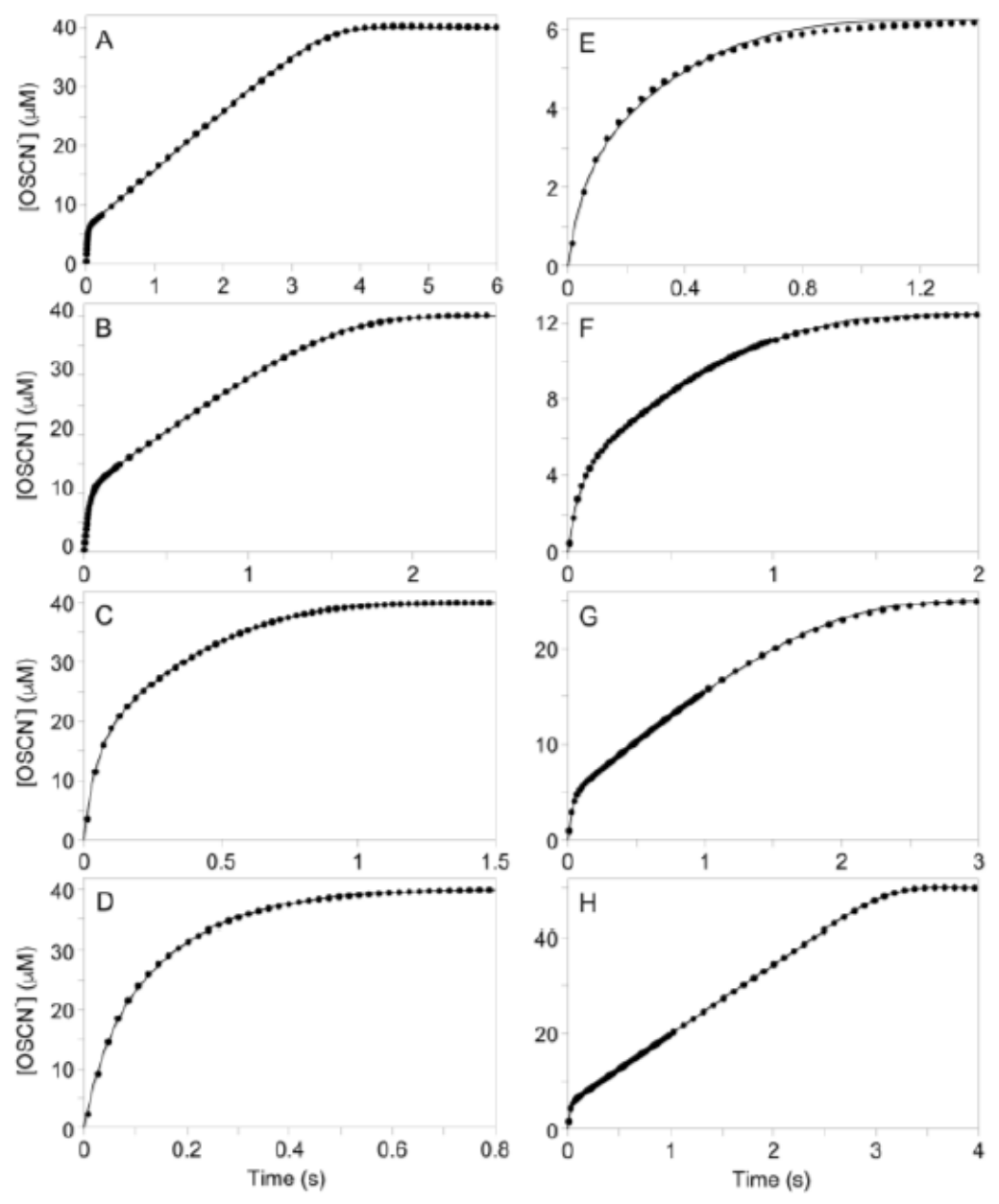

Figure 2. Experimental data (10\% shown) and least-squares fit to the model of Figure $1 \mathrm{~B}$ of the time traces for the LPO-catalyzed oxidation of $\mathrm{SCN}^{-}$by $\mathrm{H}_{2} \mathrm{O}_{2}$ under conditions of low [SCN ${ }^{-}$]. (A-D): Effect of varying [ $\left.\mathrm{SCN}^{-}\right]$. Post-mixing concentrations were $[\mathrm{LPO}]=1.2 \mu \mathrm{M},\left[\mathrm{H}_{2} \mathrm{O}_{2}\right]=40 \mu \mathrm{M}$, $[\mathrm{TNB}]=100 \mu \mathrm{M}$, and $\left[\mathrm{SCN}^{-}\right]=52,106,213$, and $425 \mu \mathrm{M}$ for A, B, C, and D, respectively. (E-H): Effect of varying $\left[\mathrm{H}_{2} \mathrm{O}_{2}\right]$. Post-mixing concentrations were $[\mathrm{LPO}]=0.5 \mu \mathrm{M},\left[\mathrm{SCN}^{-}\right]=100 \mu \mathrm{M}$, $[\mathrm{TNB}]=100 \mu \mathrm{M}$, and $\left[\mathrm{H}_{2} \mathrm{O}_{2}\right]=6.25,12.5,25$, and $50 \mu \mathrm{M}$ for $\mathrm{E}, \mathrm{F}, \mathrm{G}$, and $\mathrm{H}$, respectively. For E$\mathrm{H}$, note the change in ordinate scale due to varying $\left[\mathrm{H}_{2} \mathrm{O}_{2}\right]$. Rate constants produced by these fits are given in Tables S6 and S7. Rate constants produced when [LPO] is varied (data not shown) are given in Table S8.

\subsection{Kinetics at Low $\left[\mathrm{SCN}^{-}\right]$as a Function of $\left[\mathrm{H}_{2} \mathrm{O}_{2}\right]$}

Figure 2 Right shows the kinetic traces with varying $\left[\mathrm{H}_{2} \mathrm{O}_{2}\right]$. The first step of the biphasic reaction, which represents the pre-steady-state reaction, exhibits a first-order dependency on $\left[\mathrm{H}_{2} \mathrm{O}_{2}\right]$ (Figure S7). The $\left[\mathrm{H}_{2} \mathrm{O}_{2}\right]$ was limited to approximately $5-50 \mu \mathrm{M}$ due to detection limits of the TNB spectrophotometric assay. The number of enzyme turnovers occurring during the pre-steady-state reaction increases only slightly with increasing $\left[\mathrm{H}_{2} \mathrm{O}_{2}\right]$ and eventually, at sufficiently high $\left[\mathrm{H}_{2} \mathrm{O}_{2}\right]$, the number of enzyme turnovers that occur during the pre-steady-state reaction remains constant (Figure S8).

The rate of the steady-state reaction is largely independent of $\left[\mathrm{H}_{2} \mathrm{O}_{2}\right]$ (Table S4). The slight variation in the observed rate constants for the steady-state reaction at low $\left[\mathrm{H}_{2} \mathrm{O}_{2}\right]$ is due to inaccuracies in modeling the decreasing linear phase of the reaction (e.g., traces $\mathrm{F}$ vs. $G$ in Figure 2), which is reflected in an increased estimated error of the individual fits as $\left[\mathrm{H}_{2} \mathrm{O}_{2}\right]$ is decreased (Table S4). The independence of the rate of the steady-state reaction on $\left[\mathrm{H}_{2} \mathrm{O}_{2}\right]$ indicates either $\mathrm{H}_{2} \mathrm{O}_{2}$ is not directly involved in the reaction represented by the 
steady-state kinetics or the rate of enzyme turnover governs the rate of this reaction and steady-state active enzyme concentration is independent of $\left[\mathrm{H}_{2} \mathrm{O}_{2}\right]$.

\subsection{Kinetics at Low $\left[\mathrm{SCN}^{-}\right]$as a Function of [LPO]}

The kinetics of the steady-state reaction act predictably as [LPO] is varied for a catalysis reaction with a first-order dependence on [LPO] (Figure S9). However, when the data are fit to a biphasic kinetic model, the observed rate constant of the pre-steady-state reaction is independent of [LPO] (Table S5). Additionally, the number of turnovers that occur during the pre-steady-state reaction increases with increasing [LPO] (Figure S10). This indicates that increasing [LPO] increases the rate of turnover but has no effect on the observed rate constant of the inhibitory reaction which results in the pre-steady-state reaction (Figure S10). This would occur if the inhibitory reaction were not catalytic in nature, but rather pseudofirst-order in $\mathrm{SCN}^{-}$or $\mathrm{H}_{2} \mathrm{O}_{2}$ with respect to $\mathrm{LPO}$ (cf. the aforementioned dependencies of the pre-steady-state kinetics on $\left[\mathrm{SCN}^{-}\right]$and $\left.\left[\mathrm{H}_{2} \mathrm{O}_{2}\right]\right)$.

\subsection{Reversible Binding of $\mathrm{H}_{2} \mathrm{O}_{2}$}

In addition to concentration-dependence studies, the effect the order of mixing of LPO, $\mathrm{SCN}^{-}$, and $\mathrm{H}_{2} \mathrm{O}_{2}$ has on the reaction kinetics was also investigated. Most experiments conducted to observe the LPO-catalyzed oxidation of $\mathrm{SCN}^{-}$by $\mathrm{H}_{2} \mathrm{O}_{2}$, $\mathrm{LPO}$ and $\mathrm{SCN}^{-}$were mixed by hand, then this solution was mixed with $\mathrm{H}_{2} \mathrm{O}_{2}$ in a single mixing stopped-flow experiment. The reactions observed when this mixing order was used were biphasic as seen in Figure 3A. This mixing order was used to protect the enzyme from permanent inactivation by $\mathrm{H}_{2} \mathrm{O}_{2}$, as described in the literature [9-13]. However, to test the hypothesis that the reaction of $\mathrm{LPO}$ with $\mathrm{H}_{2} \mathrm{O}_{2}$ reversibly produces an inactive form of the enzyme, $\mathrm{H}_{2} \mathrm{O}_{2}$ was reacted with LPO to produce the inactive species in the first mixing step of a double mixing stopped-flow experiment. After an age time of one second (time to establish preequilibrium), $\mathrm{SCN}^{-}$was mixed with the $\mathrm{LPO}-\mathrm{H}_{2} \mathrm{O}_{2}$ species. When $\mathrm{LPO}$ was reacted with $\mathrm{H}_{2} \mathrm{O}_{2}$ prior to mixing with $\mathrm{SCN}^{-}$, the pre-equilibrium could no longer be observed, but the same kinetics for the zero-order phase are observed, indicating that an inactive enzyme species was reversibly produced by the reaction of $\mathrm{LPO}$ with $\mathrm{H}_{2} \mathrm{O}_{2}$ in the first mixing cycle (Figure 3B).

\subsection{Proposed Kinetic Mechanism}

The literature mechanism of Figure $1 \mathrm{~A}$ does not describe all the kinetics that we have reported herein, and specifically the kinetics observed for the LPO-catalyzed oxidation of $\mathrm{SCN}^{-}$by $\mathrm{H}_{2} \mathrm{O}_{2}$ at low $\left[\mathrm{SCN}^{-}\right.$] (Figure 2). The model of Figure $1 \mathrm{~B}$ depicts a reverse-ordered $\left(\mathrm{SCN}^{-}\right.$before $\mathrm{H}_{2} \mathrm{O}_{2}$ ) sequential mechanism with tight binding inhibition by $\mathrm{H}_{2} \mathrm{O}_{2}$. The first productive step of the reaction is the reversible binding of $\mathrm{LPO}-\left[\mathrm{Fe}^{\mathrm{III}}\right]$ and $\mathrm{SCN}^{-}$to produce LPO-SCN. This bound species then reacts irreversibly in the turnover-limiting step with $\mathrm{H}_{2} \mathrm{O}_{2}$ to produce native $\mathrm{LPO}-\left[\mathrm{Fe}^{\mathrm{III}}\right]$ and $\mathrm{OSCN}^{-}$. In addition, $\mathrm{H}_{2} \mathrm{O}_{2}$ acts as a tight binding inhibitor by reacting reversibly with native $\mathrm{LPO}-\left[\mathrm{Fe}^{\mathrm{III}}\right]$. The structure of the LPO- $\mathrm{H}_{2} \mathrm{O}_{2}$ species will be discussed later.

\subsection{Modeling of the Proposed Mechanism}

A mathematical model was constructed for the mechanism of Figure 1B (Supporting Information). To account for the TNB assay (Equation (8)), the model assigns [ $\mathrm{SCN}^{-}$] to a constant. For the model to reflect the biphasic kinetics observed experimentally, the following conditions must be met: (1) the binding equilibrium for $\mathrm{LPO}-\left[\mathrm{Fe}^{\mathrm{III}}\right]$ and $\mathrm{X}^{-}$must not be rate-limiting and lie toward the bound species, $\left(\mathrm{k}_{3}>\mathrm{k}_{4}\right)$ and $\left(\mathrm{k}_{3}>>\mathrm{k}_{-3}\right)$; (2) the reaction of $\mathrm{LPO}-\left[\mathrm{Fe}{ }^{\mathrm{III}}\right]$ with $\mathrm{H}_{2} \mathrm{O}_{2}$ to form the unproductive $\mathrm{LPO}-\mathrm{H}_{2} \mathrm{O}_{2}$ species must be competitive with the reaction of LPO-SCN with $\mathrm{H}_{2} \mathrm{O}_{2}\left(\mathrm{k}_{4} \approx \mathrm{k}_{5}\right)$; and (3) the equilibrium which produces the unproductive $\mathrm{LPO}-\mathrm{H}_{2} \mathrm{O}_{2}$ species must lie toward the $\mathrm{H}_{2} \mathrm{O}_{2}$-bound species $\left(\mathrm{k}_{5}>>\mathrm{k}_{-5}\right)$. Under these three conditions, the proposed mechanism qualitatively describes what is observed experimentally. 

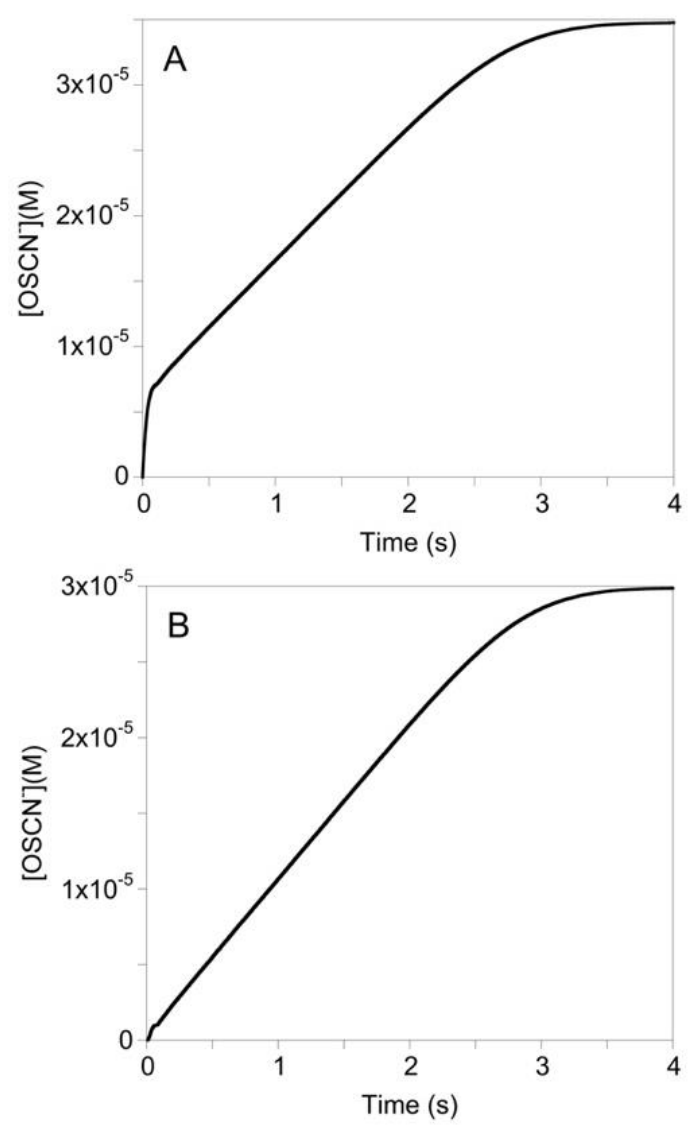

Figure 3. Kinetic traces of the LPO-catalyzed oxidation of $\mathrm{SCN}^{-}$by $\mathrm{H}_{2} \mathrm{O}_{2}$ under conditions of low concentration of $\left[\mathrm{SCN}^{-}\right]$with $(\mathrm{A})$ and without $(\mathbf{B}) \mathrm{LPO} / \mathrm{SCN}^{-}$pre-equilibrium prior to mixing with $\mathrm{H}_{2} \mathrm{O}_{2}$. For $\mathrm{A}$ and $\mathrm{B}$ : the post-mixing concentrations were [LPO] $\left.=1 \mu \mathrm{M}, \mathrm{SCN}^{-}\right]=100 \mu \mathrm{M}$, $\left[\mathrm{H}_{2} \mathrm{O}_{2}\right]=40 \mu \mathrm{M}$, and $[\mathrm{TNB}]=100 \mu \mathrm{M}$. For $\mathrm{B}$, the age time was $1 \mathrm{~s}$.

The concentration of the enzyme species predicted by the mathematical model during the pre-steady-state and steady-state phases of the reaction under various $\left[\mathrm{SCN}^{-}\right]$provides insight into the kinetics. Under conditions of high $\left[\mathrm{SCN}^{-}\right], \mathrm{LPO}-\mathrm{SCN}$ is produced rapidly and remains the primary enzyme species throughout the reaction (Figure $4 \mathrm{~A}$ ). As a result, the reaction observed under conditions of high $\left[\mathrm{SCN}^{-}\right]$is first-order with the turnoverlimiting step being the reaction of LPO-SCN with $\mathrm{H}_{2} \mathrm{O}_{2}$ (Figure S11). When [ $\mathrm{SCN}^{-}$] is low, the rapid equilibrium binding of native $\mathrm{LPO}-\left[\mathrm{Fe}^{\mathrm{III}}\right]$ by $\mathrm{SCN}^{-}$causes the fast production of the active LPO-SCN species. The competitive rate of $\mathrm{k}_{4}$ and $\mathrm{k}_{5}$ as well as the tight binding of $\mathrm{H}_{2} \mathrm{O}_{2}$ to native LPO-[Fe $\left.{ }^{\mathrm{III}}\right]$ causes a relatively slow conversion from LPO-SCN as the primary enzyme species to the unproductive species LPO- $\mathrm{H}_{2} \mathrm{O}_{2}$ (Figure 4B). As LPO-SCN is the productive enzyme species in the turnover limiting step, the unproductive species LPO- $\mathrm{H}_{2} \mathrm{O}_{2}$ causes a decrease in the rate of $\mathrm{OSCN}^{-}$production (Figure S12). After steadystate concentrations have been reached, the reaction becomes zeroth-order (Figure S13). During the steady-state reaction, the concentration of the unproductive enzyme species, LPO- $\mathrm{H}_{2} \mathrm{O}_{2}$, slowly decreases and is replaced by the $\mathrm{SCN}^{-}$bound species, LPO-SCN. Thereafter, until $\mathrm{H}_{2} \mathrm{O}_{2}$ has been depleted and the reaction is complete, LPO-SCN remains the primary enzyme species (Figure $4 \mathrm{~B}$ ).

\subsection{Fitting the Experimental Data}

The aforementioned Mathematica model was used to fit experimental data and to calculate the rate constants. The data for which the pre-steady-state reactions were well resolved from the steady-state reactions, as in Figure 2A,B, were easily fit by the model and all the rate constants were fit simultaneously. However, the rate constants for the 
data in which the pre-steady-state and steady-state reactions were not well resolved, as in Figure 2C, could not be fit simultaneously. In these cases, rate constants which were not primary to the observed kinetics were fixed so the rate constants related to the reactions which were dominant could be calculated (Tables S6-S8). Representative fits of the kinetic data when the $\left[\mathrm{SCN}^{-}\right]$and $\left[\mathrm{H}_{2} \mathrm{O}_{2}\right]$ were varied are illustrated in Figure 2. Representative fits of the kinetic data when he [LPO] was varied are illustrated in Figure S14. Table 1 summarizes the average calculated rate constants for the model proposed in Figure $1 \mathrm{~B}$. The predictions made concerning the relative magnitudes of the rate constants appear to be correct, i.e., $\left(\mathrm{k}_{3}>\mathrm{k}_{4}\right),\left(\mathrm{k}_{3}>>\mathrm{k}_{-3}\right),\left(\mathrm{k}_{4} \approx \mathrm{k}_{5}\right)$, and $\left(\mathrm{k}_{5}>>\mathrm{k}_{-5}\right)$. The rate constant $\mathrm{k}_{3}$ is near diffusion-controlled.

Table 1. Apparent Rate Constants for the Mechanisms of Figure 1. Estimated error of the leastsignificant figure given in parentheses.

\begin{tabular}{cccc}
\hline Constant & Value & Temp $\left({ }^{\circ} \mathbf{C}\right)$ & Source \\
\hline $\mathrm{k}_{1}$ & $1.1 \times 10^{7} \mathrm{M}^{-1} \mathrm{~s}^{-1}$ & 15 & 3 \\
$\mathrm{k}_{2}$ & $2.0 \times 10^{8} \mathrm{M}^{-1} \mathrm{~s}^{-1}$ & 15 & 3 \\
$\mathrm{k}_{3}$ & $1.4(2) \times 10^{9} \mathrm{M}^{-1} \mathrm{~s}^{-1}$ & 25 & this study \\
$\mathrm{k}_{-3}$ & $3.94(5) \times 10^{3} \mathrm{~s}^{-1}$ & 25 & this study \\
$\mathrm{k}_{4}$ & $1.0(3) \times 10^{7} \mathrm{M}^{-1} \mathrm{~s}^{-1}$ & 25 & this study \\
$\mathrm{k}_{5}$ & $3(1) \times 10^{7} \mathrm{M}^{-1} \mathrm{~s}^{-1}$ & 25 & this study \\
$\mathrm{k}_{-5}$ & $1.9(4) \mathrm{s}^{-1}$ & 25 & this study \\
\hline
\end{tabular}

\subsection{The Structure of LPO- $\mathrm{H}_{2} \mathrm{O}_{2}$}

The simulation of Figure $4 \mathrm{~B}$ predicts the intermediate species $\mathrm{LPO}-\mathrm{H}_{2} \mathrm{O}_{2}$ should accumulate during catalysis in the presence of low $\left[\mathrm{SCN}^{-}\right]$. Time-resolved spectra were collected (in the absence of TNB) and subjected to singular value decomposition analysis. Model-free analysis predicted two colored species, but it was subsequently determined that the model of Figure $1 \mathrm{~B}$ required the electronic spectrum of $\mathrm{LPO}-\left[\mathrm{Fe}^{\mathrm{III}}\right]$ to be similar to LPO-SCN. In reality, binding of $\mathrm{SCN}^{-}$to $\mathrm{LPO}$ results in a $\mathrm{pH}$-dependent red shift of 1-4 $\mathrm{nm}$ [14], which is not resolved by the rapid-scan diode-array of the stopped-flow instrument. It is not surprising that the spectra of LPO and LPO-SCN are similar as SCN ${ }^{-}$ is known to bind remotely relative to the iron-heme chromophore [15]. Subsequent singular value decomposition analysis yields a spectrum similar to $\mathrm{LPO}-\left[\mathrm{Fe}^{\mathrm{III}}\right]$, albeit red-shifted by about $1 \mathrm{~nm}$ (which we interpret is actually LPO-SCN, cf. Figure 4B), and a spectrum that appears to be Compound II (Cpd II-[Fe $\left.{ }^{\mathrm{IV}}-\mathrm{OH}\right]$, without a radical on the porphyrin or amino acid backbone). Cpd II-like species are known to form spontaneously from Cpd I [2]. Electronic absorption spectra do not distinguish between true Cpd II species, which are the result of one-electron reduction of Cpd I, and species like Cpd I- $\left[\mathrm{Fe}^{\mathrm{IV}}-\mathrm{OH}\right.$, $\mathrm{aa}^{+}$], where the radical has moved from the porphyrin to an amino acid, but EPR can distinguish these species [16]. Since the $\mathrm{LPO}-\mathrm{H}_{2} \mathrm{O}_{2}$ species forms reversibly in the absence of one-electron donors (Figure 6A) and the deconvoluted spectrum is identical to Cpd $\mathrm{I}^{*}-\left[\mathrm{Fe}^{\mathrm{IV}}-\mathrm{OH}, \mathrm{aa}^{+\cdot}\right]$ (Figure $6 \mathrm{~B}$, in addition to the Soret band at 431, the Q-bands at 536 and 565 are diagnostic) $[3,17]$, we conclude the latter is $\mathrm{LPO}-\mathrm{H}_{2} \mathrm{O}_{2}$. We note there is kinetic and spectroscopic evidence that protein radicals are formed during LPO turnover $[16,18]$. While the electronic spectra of $\mathrm{Cpd} \mathrm{I} \mathrm{I}_{-}-\left[\mathrm{Fe}^{\mathrm{IV}}-\mathrm{OH}\right.$, aa $\left.{ }^{+\cdot}\right]$ and $\mathrm{Cpd}$ II- $\left[\mathrm{Fe}^{\mathrm{IV}}-\mathrm{OH}\right]$ are similar, we ruled out $\mathrm{Cpd}$ II- $\left[\mathrm{Fe}^{\mathrm{IV}}=\mathrm{O}\right]$ for $\mathrm{LPO}-\mathrm{H}_{2} \mathrm{O}_{2}$ because it is known to be stable for more than five minutes [19] and because the formation of $\mathrm{LPO}-\mathrm{H}_{2} \mathrm{O}_{2}$ is reversible (cf. Figures 3 and 6A). Importantly, a clean isosbestic point exists at $420 \mathrm{~nm}$ for the conversion of LPO-[Fe $\left.{ }^{\mathrm{III}}\right]$ to $\mathrm{Cpd} \mathrm{I*}-\left[\mathrm{Fe}^{\mathrm{IV}}-\mathrm{OH}, \mathrm{aa}^{+\cdot}\right]$ during catalysis (Figure 6). In contrast, the isomerization of $\mathrm{Cpd} \mathrm{I}-\left[\mathrm{Fe}^{\mathrm{IV}}=\mathrm{O}, \pi^{+\cdot}\right]$ to $\mathrm{Cpd} \mathrm{I} \mathrm{I}^{*}-\left[\mathrm{Fe}^{\mathrm{IV}}-\mathrm{OH}, \mathrm{aa}^{+\cdot}\right]$ occurs with a rate constant of $2 \mathrm{~s}^{-1}[3]$ and the reaction has an isosbestic point at $408 \mathrm{~nm}$ [18]. The presence of the isosbestic point at $420 \mathrm{~nm}$ in Figure 6 and a simulation (Figure S15) show that the production of Cpd

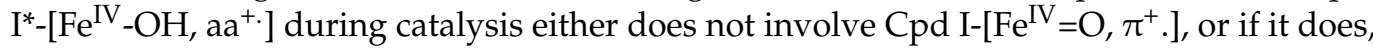
the conversion of $\mathrm{Cpd} \mathrm{I-}\left[\mathrm{Fe}^{\mathrm{IV}}=\mathrm{O}, \pi^{+\cdot}\right]$ to $\mathrm{Cpd} \mathrm{I}{ }^{*}-\left[\mathrm{Fe}^{\mathrm{IV}}-\mathrm{OH}, \mathrm{aa}^{+\cdot}\right]$ has been accelerated. In 
our model, $\mathrm{LPO}-\mathrm{H}_{2} \mathrm{O}_{2}$ does not react directly with $\mathrm{SCN}^{-}$, which implies $\mathrm{Cpd} \mathrm{I}-\left[\mathrm{Fe}^{\mathrm{IV}}=\mathrm{O}\right.$, $\pi^{+}$] is not captured by $\mathrm{SCN}^{-}$during catalysis.

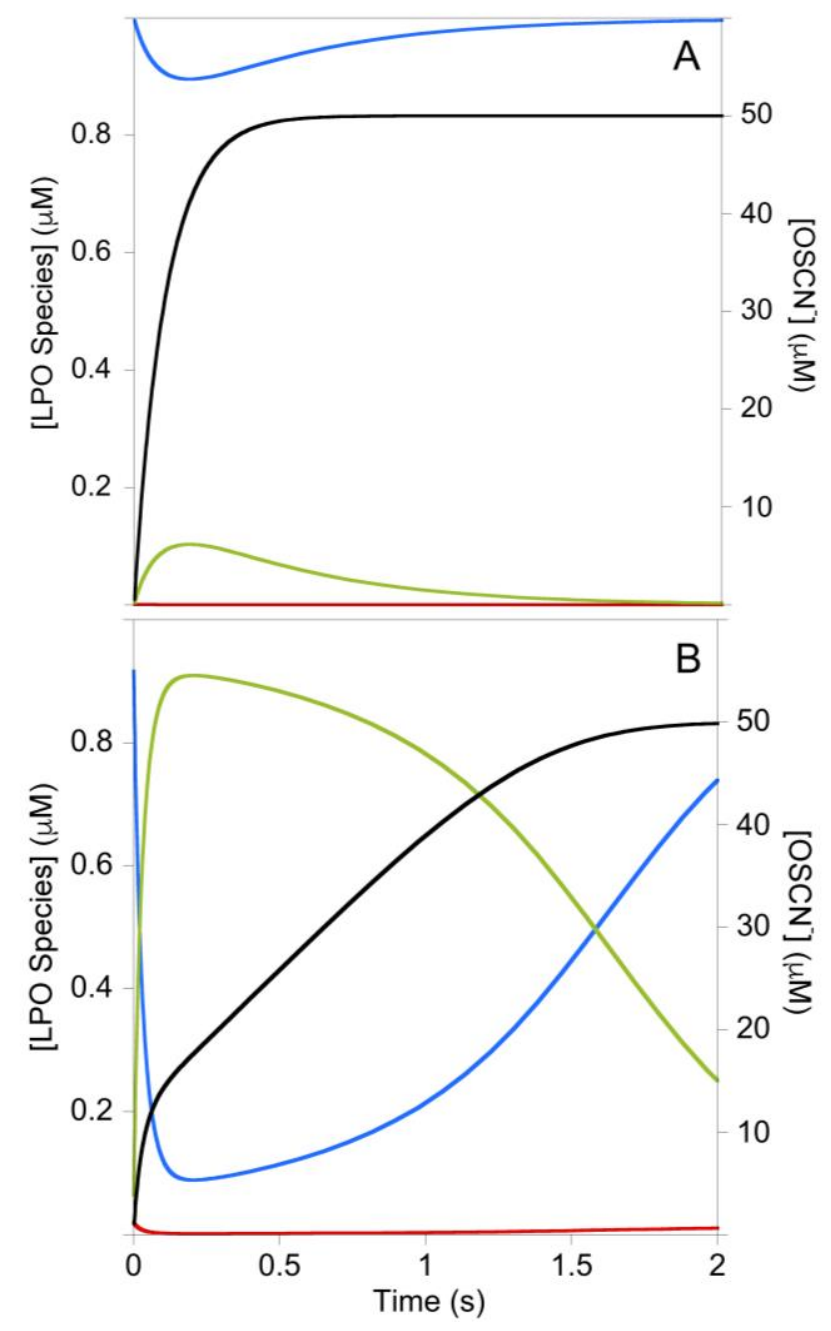

Figure 4. Simulated concentrations during the LPO-catalyzed oxidation of $\mathrm{SCN}^{-}$by $\mathrm{H}_{2} \mathrm{O}_{2}$ for the mechanism of Figure $1 \mathrm{~B}$ under high $(\mathbf{A})$ and low $(\mathbf{B})\left[\mathrm{SCN}^{-}\right]$conditions: Red $=\mathrm{LPO}-\left[\mathrm{Fe}^{\mathrm{III}}\right]$, Blue $=\mathrm{LPO}-\mathrm{SCN}$, Green $=\mathrm{Cpd} \mathrm{I}{ }^{*}$, Black $=\mathrm{OSCN}^{-}$. For A and B: $\mathrm{k}_{3}=1.4 \times 10^{9} \mathrm{M}^{-1} \mathrm{~s}^{-1}$, $\mathrm{k}_{-3}=1000 \mathrm{~s}^{-1} ; \mathrm{k}_{4}=1 \times 10^{7} \mathrm{M}^{-1} \mathrm{~s}^{-1} ; \mathrm{k}_{5}=3.48 \times 10^{7} \mathrm{M}^{-1} \mathrm{~s}^{-1}, \mathrm{k}_{-5}=2.07 \mathrm{~s}^{-1} ;[\mathrm{LPO}]_{0}=1 \mu \mathrm{M}$; $\left[\mathrm{H}_{2} \mathrm{O}_{2}\right]_{0}=50 \mu \mathrm{M}$. For A: $\left[\mathrm{SCN}^{-}\right]_{0}=1 \mathrm{mM}$. For B: $\left[\mathrm{SCN}^{-}\right]_{0}=50 \mu \mathrm{M}$. The conditions of Figure $4 \mathrm{~B}$ are approximately the same as Figure $2 \mathrm{~A}$. This simulation assumes the $\left[\mathrm{SCN}^{-}\right]$remains constant, as expected for the stoichiometry of the TNB assay. The results of Figure $4 \mathrm{~B}$ may be compared with a simulation of the mechanism of Figure 1B that included the known rate of conversion of Cpd I to Cpd I* (Figure S15), which predicts LPO-[Fe $\left.{ }^{\mathrm{III}}\right]$ is the steady-state species and the reaction is pseudo-first-order.

\subsection{Proposed Intimate Mechanism}

While the kinetic mechanism of Figure 1B is consistent with the experimental results that are presented herein, it does not identify the species formed when LPO-SCN reacts with $\mathrm{H}_{2} \mathrm{O}_{2}$, nor does it offer insight into why the sequence of substrate addition is important. Regarding the species formed after the turnover-limiting step of catalysis, it is likely a Compound I-like species, albeit bound by $\mathrm{SCN}^{-}$, although none of our results address its structure. Regarding the sequence of substrate addition, the intimate mechanism must involve an interplay of redox potentials, acid/base properties, and activation barriers that are influenced by molecular geometrics. We offer the following interpretation that 
is based upon several extrakinetic observations. The distal heme cavity is connected to the surface by a $22 \AA$-long substrate diffusion channel that is lined by hydrophobic residues [20]. A hydrogen bonded chain involving $\mathrm{Fe}^{3+}-\mathrm{W}_{1}-\mathrm{His}_{109}-\mathrm{W}_{2}-\mathrm{His}_{266}-\mathrm{W}_{3}-\mathrm{W}_{4}-\mathrm{W}_{5}-$ $\mathrm{W}_{6}-\mathrm{Ala}_{214}$ within the substrate diffusion channel connects the heme to the surface, where $\mathrm{His}_{109}$ is believed to be a key proton donor at the heme and waters $\mathrm{W}_{1-6}$ are generally conserved [20]. The $\mathrm{pK}_{\mathrm{a}}$ of HSCN is -1.4 (so it is an anion that must be charge-neutralized in the binding pocket). $\mathrm{SCN}^{-}$binds in the distal heme cavity by displacing two of the conserved waters, thereby disrupting the hydrogen bond chain [20]. Finally, $\mathrm{Cpd} \mathrm{I} \mathrm{I}^{*}\left[\mathrm{Fe}^{\mathrm{IV}}\right.$ $\left.\mathrm{OH}, \mathrm{aa}^{+} \cdot\right]$ is protonated at the terminal oxo ligand (which is curious as $\mathrm{Cpd} \mathrm{I-}\left[\mathrm{Fe}^{\mathrm{IV}}=\mathrm{O}, \pi^{++}\right]$is not) [6-8]. Figure 5 summarizes the potential LPO species that are involved in catalysis. The turn-over limiting step (Figure 1B, Equation (4)) involves a rate-limiting reaction of $\mathrm{H}_{2} \mathrm{O}_{2}$ with $\mathrm{LPO}-\left[\mathrm{Fe}^{\mathrm{III}}\right] \cdot \mathrm{SCN}^{-}$to presumably give $\mathrm{Cpd} \mathrm{I}-\left[\mathrm{Fe}^{\mathrm{IV}}=\mathrm{O}, \pi^{+}\right] \cdot \mathrm{SCN}^{-}$. Histidines that are buried in proteins $\left(\mathrm{pK}_{\mathrm{a}}=\sim 7 \pm 1\right)$ tend to be less acidic than free histidine $\left(\mathrm{pK}_{\mathrm{a}}=\sim 6\right)$ [21]. The large variation of His $\mathrm{pK}_{\mathrm{a}}$ in proteins reflects intrinsic differences due to the specific environment of each residue. The optimal $\mathrm{pH}$ for the LPO system is $\sim 6$, although the optimal value depends on the particular substrate [22]. It is likely the variability is due to the local environments of $\mathrm{His}_{109}$ and/or $\mathrm{His}_{266}$ (as well as other residues). We propose the proximity of the anionic $\mathrm{SCN}^{-}$substrate combined with the disruption of the hydrogen bond chain increases the $\mathrm{pK}_{\mathrm{a}}$ of $\mathrm{His}_{109}$, preventing it from stabilizing the oxo ligand of Cpd I-[Fe $\left.{ }^{\mathrm{IV}}=\mathrm{O}, \pi^{+} \cdot\right] \cdot \mathrm{SCN}^{-}$(Figure 5) and facilitating the reaction of LPO-[Fe $\left.{ }^{\mathrm{III}}\right] \cdot \mathrm{SCN}^{-}$with $\mathrm{H}_{2} \mathrm{O}_{2}$ (Figure 1B, Equation (4)). In contrast, in the absence of $\mathrm{SCN}^{-}$, $\mathrm{His}_{109}$ is capable of protonating the oxo ligand of $\mathrm{Cpd} \mathrm{I}-\left[\mathrm{Fe}^{\mathrm{IV}}=\mathrm{O}, \pi^{+} \cdot\right]$, thereby converting it to $\mathrm{Cpd} \mathrm{I} \mathrm{I}^{*}\left[\mathrm{Fe}^{\mathrm{IV}}\right.$ $\mathrm{OH}, \mathrm{aa}^{+}$] by facilitating electron transfer. The intimate model of Figure 5 furthermore suggests reasons why $\mathrm{LPO}-\left[\mathrm{Fe}^{\mathrm{III}}\right]$ binds $\mathrm{SCN}^{-}$, whereas, due to conflict in $\mathrm{H}$-bonding, $\mathrm{Cpd}$ $\mathrm{I}^{*}-\left[\mathrm{Fe}^{\mathrm{IV}}-\mathrm{OH}, \mathrm{aa}^{+\cdot}\right]$ does not.

\section{LPO-[Fe' $\left.{ }^{\prime \prime \prime}\right]=$ LPO-[Fe $\left.{ }^{\prime \prime \prime}\right] \cdot \mathrm{SCN}^{-}=$}

Cpd I-[Fe $\left.\mathrm{IV}^{\mathrm{I}}=0, \pi^{+\cdot}\right]=$

Cpd I*-[Felv-OH, aa+] $=$

Cpd I-[Fe $\left.\mathrm{IV}^{\mathrm{IV}}=0, \pi^{+}\right] \cdot \mathrm{SCN}^{-}=$

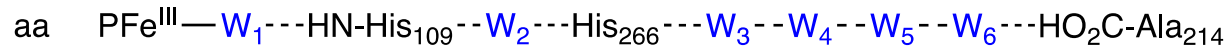

$$
\begin{aligned}
& \text { aa } \mathrm{PFe} \text { III }-\mathrm{W}_{1} \rightarrow \mathrm{HN}-\mathrm{His}_{109} \rightarrow \mathrm{W}_{2} \rightarrow \mathrm{His}_{266} \rightarrow \mathrm{W}_{3} \rightarrow-\mathrm{S}-\mathrm{C} \equiv \mathrm{N} \leftarrow \mathrm{W}_{6} \leftarrow \mathrm{HO}_{2} \mathrm{C}-\mathrm{Ala}_{214} \\
& \text { aa } \mathrm{P}^{+\cdot} \mathrm{Fe}^{\mathrm{IV}}=\mathrm{O} \leftarrow \mathrm{HN}-\mathrm{His}_{109}-\mathrm{W}_{2} \leftarrow \mathrm{His}_{266} \leftarrow \mathrm{W}_{3} \leftarrow \mathrm{W}_{4} \leftarrow \mathrm{W}_{5} \leftarrow \mathrm{W}_{6} \leftarrow \mathrm{HO}_{2} \mathrm{C}-\mathrm{Ala}_{214}
\end{aligned}
$$

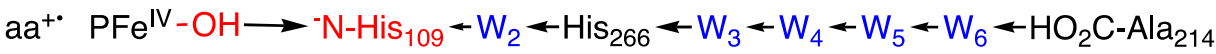

$$
\begin{aligned}
& \text { aa } \mathrm{P}^{+\cdot} \mathrm{Fe} \mathrm{IV}^{\mathrm{IV}}=\mathrm{O} \quad \mathrm{HN}-\mathrm{His}_{109} \rightarrow \mathrm{W}_{2} \rightarrow \mathrm{His}_{266} \rightarrow \mathrm{W}_{6} \rightarrow-\mathrm{S}-\mathrm{C} \equiv \mathrm{N}-\mathrm{W}_{6} \rightarrow \mathrm{HO}_{2} \mathrm{C}-\mathrm{Ala}_{214}
\end{aligned}
$$

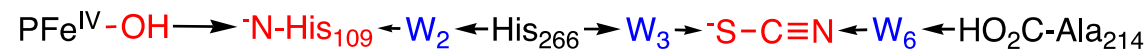

Figure 5. Proposed intimate mechanism for the LPO-catalyzed oxidation of thiocyanate and inhibition by hydrogen peroxide. Significant modifications to the resting state are indicated in red and the resulting changes in $\mathrm{H}$-bond donation are indicated by arrows. LPO-[Fe $\left.{ }^{\mathrm{III}}\right]$ is stabilized by an aqua ligand $\left(\mathrm{W}_{1}\right)$ that is connected to a H-bonded chain the extends

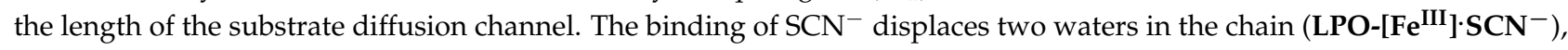
whereupon $\mathrm{H}$-bond donation is reorganized to stabilize the negative charge on $\mathrm{SCN}^{-}$. The oxo ligand $\left(\mathrm{O}^{2-}\right)$ is stabilized by the H-bond change in $\mathbf{C p d} \mathbf{I}-\left[\mathrm{Fe}^{\mathbf{I V}}=\mathbf{O}, \pi^{+\cdot}\right]$. Proton transfer to Cpd I coupled with electron donation by an amino acid yield $\mathrm{Cpd} \mathrm{I}^{*}-\left[\mathrm{Fe}^{\mathrm{IV}}-\mathrm{OH}, \mathbf{a a}^{+\cdot}\right]$, where His 109 anion is stabilized by the H-bond chain. The binding of SCN ${ }^{-}$to $\mathrm{Cpd}_{\mathrm{I}}$ results reorganizes the $\mathrm{H}$-bond chain $\left.\mathrm{Cpd} \mathrm{I-[Fe} \mathrm{IV}^{\mathrm{IV}}=\mathrm{O}, \pi^{+\cdot} \cdot\right] \cdot \mathrm{SCN}^{-}$to stabilize $\mathrm{SCN}^{-}$while destabilizing the $\left[\mathrm{Fe}^{\mathrm{IV}}=\mathrm{O}\right]$ moiety. The binding of $\mathrm{SCN}^{-}$to $\mathrm{Cpd} \mathrm{I} \mathrm{I}^{*}$ results in conflict in the $\mathrm{H}$-bond chain of $\mathrm{Cpd} \mathrm{I}^{*}\left[\mathrm{Fe}^{\mathrm{IV}_{-}}-\mathbf{O H}, \mathbf{a a}^{+\cdot}\right] \cdot \mathbf{S C N}^{-}$.

Biological relevance. The physiological relevance of the mechanism of Figure 1B may be traced to the role of LPO in health and disease. LPO is secreted by mucosal glands to body fluids including breast milk, salivary, lachrymal, and airway secretions. In general, health is associated with relatively high $\left[\mathrm{SCN}^{-}\right]$and low $\left[\mathrm{H}_{2} \mathrm{O}_{2}\right]$. However, disease states frequently reduce $\left[\mathrm{SCN}^{-}\right]$and increase $\left[\mathrm{H}_{2} \mathrm{O}_{2}\right]$, and LPO activity is consequently impaired for diseases like caries [23], cystic fibrosis [24], and neonatal pathologies [25]. 

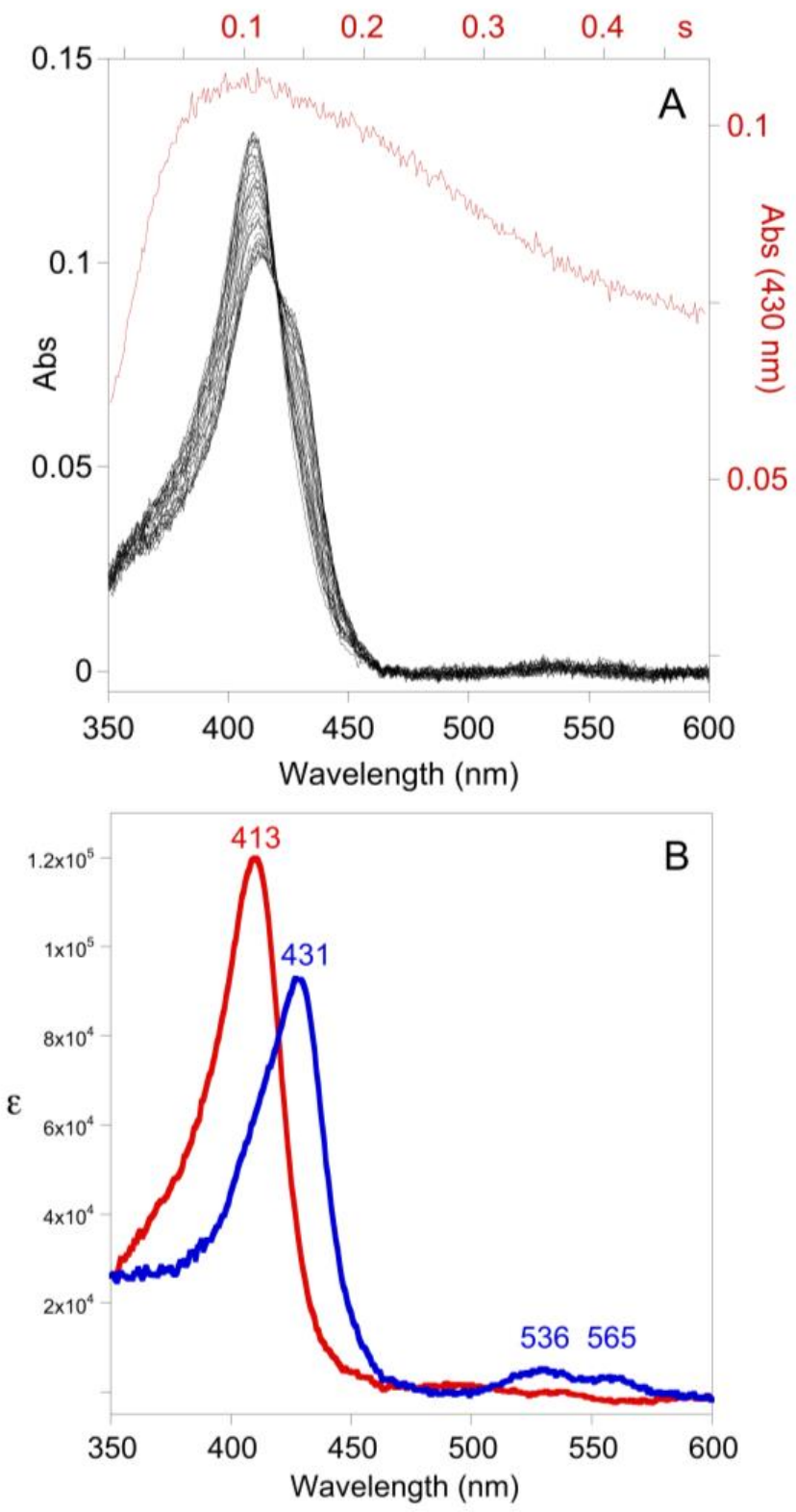

Figure 6. (A) Time-resolved UV-visible spectra (10\% of data shown) and trace at $430 \mathrm{~nm}$ (cf. the green trace of Figure $4 \mathrm{~B}$ ). Post-mixing concentrations were $[\mathrm{LPO}]=1.2 \mu \mathrm{M},\left[\mathrm{H}_{2} \mathrm{O}_{2}\right]=40 \mu \mathrm{M}$, and $\left[\mathrm{SCN}^{-}\right]=52 \mu \mathrm{M}$ at $\mathrm{pH}$ 7. (B) Deconvoluted color components from singular value decomposition of the time-resolved spectra of A, LPO-[Fe $\left.{ }^{\mathrm{III}}\right] / \mathrm{LPO}-\mathrm{SCN}$ (red) and $\mathrm{Cpd} \mathrm{I}{ }^{*}\left[\mathrm{Fe}^{\mathrm{IV}}-\mathrm{OH}, \mathrm{aa}^{+\cdot}\right]$ (blue).

Low $\left[\mathrm{SCN}^{-}\right.$] develops through two distinct mechanisms in vivo, defective transport and chemical reaction. Endocrine fluids are generally characterized by high [SCN $\left.{ }^{-}\right]$. For example, active transport into airway secretions and saliva of non-smokers produce about $500 \mu \mathrm{M} \mathrm{SCN}^{-}$(although $\mathrm{mM}$ concentrations are observed for smokers), which is orders of magnitude higher than plasma, which is typically $35 \mu \mathrm{M}[26,27]$. In contrast, $\mathrm{SCN}^{-}$ release is absent in lung epithelial cells from mutations in the cystic fibrosis transmembrane conductance regulator (CFTR) [28,29]. Furthermore, xerostomia (dry mouth) —often a side effect of certain medications, aging issues, or as a result of radiation therapy for cancer-renders the principal source of $\mathrm{SCN}^{-}$in the oral cavity ineffective. Even when transport is functional, low [SCN ${ }^{-}$] can result from a local chemical reaction, especially under conditions of oxidative stress that deplete thiols, the exclusive reactants of $\mathrm{OSCN}^{-}$. Without reaction partners, $\mathrm{OSCN}^{-}$rapidly decomposes through irreversible processes, 
thereby yielding a pathway that chemically depletes $\mathrm{SCN}^{-}$[30]. Both mechanisms can reduce $\mathrm{SCN}^{-}$to concentrations comparable to Figure $4 \mathrm{~B}$.

High $\left[\mathrm{H}_{2} \mathrm{O}_{2}\right]$ can be produced by the host and by certain infectious agents. Concentrations of $\mathrm{H}_{2} \mathrm{O}_{2}$ in excess of $100 \mu \mathrm{M}$ in human physiological fluids are not uncommon [31]. Some human pathogens, such as mutans streptococci (including cariogenic Streptococcus mutans and S. sobrinus), accumulate up to $2 \mathrm{mM} \mathrm{H}_{2} \mathrm{O}_{2}$ in their media during growth on glucose [32]. While $\mathrm{H}_{2} \mathrm{O}_{2}$ is present in the air exhaled by healthy human subjects, amounts of exhaled $\mathrm{H}_{2} \mathrm{O}_{2}$ appear greater in subjects with inflammatory lung diseases and in cigarette smokers [31].

At sufficient concentrations, $\mathrm{H}_{2} \mathrm{O}_{2}$ is cytotoxic to mammalian cell lines, including human epithelial cells [33] and gingival fibroblasts [34,35]. In the presence of $\mathrm{SCN}^{-}$, the $\mathrm{LPO}$ system protects cultured mammalian cells against $\mathrm{H}_{2} \mathrm{O}_{2}$ toxicity [36]. This is consistent with the observation that $\mathrm{OSCN}^{-}$is not toxic toward mammalian cells $[37,38]$. It has been previously suggested that one of the important roles of human peroxidases is to detoxify $\mathrm{H}_{2} \mathrm{O}_{2}$ to prevent host tissue damage [39,40]. It is generally assumed that detoxification occurs during the consumption of $\mathrm{H}_{2} \mathrm{O}_{2}$ to produce $\mathrm{OSCN}^{-}$. However, that process is retarded when the $\left[\mathrm{H}_{2} \mathrm{O}_{2}\right]$ is high and the $\left[\mathrm{SCN}^{-}\right]$is low (cf. Figure $4 \mathrm{~A}$ vs. Figure $4 \mathrm{~B}$ ), conditions that are favored in disease and that promote the accumulation of $\mathrm{Cpd} \mathrm{I} \mathrm{I}_{-}\left[\mathrm{Fe}^{\mathrm{IV}}\right.$ $\mathrm{OH}, \mathrm{aa}^{+}$. . Furthermore, LPO is an ineffectual catalase [41]. Accordingly, not only must the LPO mechanism be revised, but the physiological behavior of LPO in disease requires further consideration in the context of our findings. In addition, the mechanisms of other members of the human peroxidase family, especially myeloperoxidase and eosinophil peroxidase, should be reexamined.

\section{Conclusions}

To account for new data that are inconsistent with the previously accepted mechanism for the LPO-catalyzed oxidation of $\mathrm{SCN}^{-}$by $\mathrm{H}_{2} \mathrm{O}_{2}$, an ordered sequential mechanism is proposed herein where the order of substrate binding is reversed, first $\mathrm{SCN}^{-}$and then $\mathrm{H}_{2} \mathrm{O}_{2}$. In the new model, the sequence of substrate binding that is described by the literature halogen cycle mechanism is inhibitory. As the reaction conditions that give rise to the proposed catalytic mechanism may be biologically relevant, the role of LPO in human physiology deserves further consideration.

Supplementary Materials: The following are available online at https:/ / www.mdpi.com/article/10 .3390 /antiox10111646/s1, a discussion of related literature for myeloperoxidase (MPO), Mathematica code for fitting and modeling the data, Figure S1: Reaction mixing scheme for the single mixing stopped-flow experiment to observe the rate of the LPO-catalyzed oxidation of $\mathrm{SCN}^{-}$by $\mathrm{H}_{2} \mathrm{O}_{2}$ at $\mathrm{pH}$ 7., Figure S2: Reaction mixing scheme for the double mixing stopped-flow experiment to observe the effect of mixing $\mathrm{LPO}$ and $\mathrm{SCN}^{-}$in the first mixing cycle prior to the addition of $\mathrm{H}_{2} \mathrm{O}_{2}$ on the LPO-catalyzed oxidation of $\mathrm{SCN}^{-}$by $\mathrm{H}_{2} \mathrm{O}_{2}$ at neutral $\mathrm{pH}$, Figure S3: Reaction mixing scheme for the double mixing stopped-flow experiment to observe the effect of mixing LPO and $\mathrm{H}_{2} \mathrm{O}_{2}$ in the first mixing cycle prior to the addition of $\mathrm{SCN}^{-}$on the $\mathrm{LPO}$-catalyzed oxidation of $\mathrm{SCN}^{-}$by $\mathrm{H}_{2} \mathrm{O}_{2}$ at neutral $\mathrm{pH}$, Figure $\mathrm{S} 4$ : Isolated view of the pre-steady-state reaction observed in Figure 2 (left) for the LPO-catalyzed oxidation of $\left[\mathrm{SCN}^{-}\right]$by $\mathrm{H}_{2} \mathrm{O}_{2}$ under low $\left[\mathrm{SCN}^{-}\right]$conditions, Figure S5: Observed first-order rate constants for the pre-steady-state reaction in the LPO-catalyzed oxidation of $\mathrm{SCN}^{-}$by $\mathrm{H}_{2} \mathrm{O}_{2}$., Figure S6: Effect of varying $\left[\mathrm{SCN}^{-}\right]$on the rate of the steady-state reaction during the LPO-catalyzed oxidation of $\mathrm{SCN}^{-}$by $\mathrm{H}_{2} \mathrm{O}_{2}$, Figure S7: Effect of $\left[\mathrm{H}_{2} \mathrm{O}_{2}\right]$ on $\mathrm{k}_{1 \text { obs }}$ for the LPO-catalyzed oxidation of $\mathrm{SCN}^{-}$by $\mathrm{H}_{2} \mathrm{O}_{2}$ under conditions of low concentration of [SCN ${ }^{-}$], Figure S8: Kinetic traces of the pre-steady-state reaction observed during the LPO-catalyzed oxidation of $\mathrm{SCN}^{-}$by $\mathrm{H}_{2} \mathrm{O}_{2}$ as $\left[\mathrm{H}_{2} \mathrm{O}_{2}\right]$ was varied, Figure S9: Steady-state reaction rate dependence on [LPO] for the LPO-catalyzed oxidation of $\mathrm{SCN}^{-}$by $\mathrm{H}_{2} \mathrm{O}_{2}$, Figure $\mathrm{S} 10$ : Kinetic traces of pre-steady-state reaction of the LPO-catalyzed oxidation of $\mathrm{SCN}^{-}$by $\mathrm{H}_{2} \mathrm{O}_{2}$ as [LPO] is varied, Figure S11: Simulated trace of $\left[\mathrm{OSCN}^{-}\right.$] for the proposed mechanism for the LPO-catalyzed oxidation of $\mathrm{SCN}^{-}$by $\mathrm{H}_{2} \mathrm{O}_{2}$ under conditions of high $\left[\mathrm{SCN}^{-}\right]$, Figure S12: Simulated trace of $\left[\mathrm{OSCN}^{-}\right]$during the pre-steady-state reaction for the proposed mechanism for the LPO-catalyzed oxidation of $\mathrm{SCN}^{-}$by $\mathrm{H}_{2} \mathrm{O}_{2}$ under 
conditions of low $\left[\mathrm{SCN}^{-}\right]$, Figure S13: Simulated trace of $\left[\mathrm{OSCN}^{-}\right]$during the reaction for the proposed mechanism for the LPO-catalyzed oxidation of $\mathrm{SCN}^{-}$by $\mathrm{H}_{2} \mathrm{O}_{2}$ under conditions of low $\left[\mathrm{SCN}^{-}\right.$], Figure S14: Fitted kinetic traces for the LPO-catalyzed oxidation of $\mathrm{SCN}^{-}$by $\mathrm{H}_{2} \mathrm{O}_{2}$ as [LPO] was varied, Figure S15: Simulated concentrations during the LPO-catalyzed oxidation of $\mathrm{SCN}^{-}$by $\mathrm{H}_{2} \mathrm{O}_{2}$ for the mechanism of Figure 1A with the additional known step for the conversion of Cpd I to Cpd I*, Table S1: Observed rate of the LPO-catalyzed oxidation of $\mathrm{SCN}^{-}$by $\mathrm{H}_{2} \mathrm{O}_{2}$ as a function of $\left[\mathrm{H}_{2} \mathrm{O}_{2}\right]$, Table S2: Observed rate of the LPO-catalyzed oxidation of $\mathrm{SCN}^{-}$by $\mathrm{H}_{2} \mathrm{O}_{2}$ as a function of $\left[\mathrm{SCN}^{-}\right]$, Table S3: Observed initial rates of the LPO-catalyzed oxidation of $\mathrm{SCN}^{-}$by $\mathrm{H}_{2} \mathrm{O}_{2}$ as a function of $\left[\mathrm{SCN}^{-}\right]$, Table S4: Effect of varying $\left[\mathrm{H}_{2} \mathrm{O}_{2}\right]$ on the rate of the steady-state reaction of the LPO-catalyzed oxidation of $\mathrm{SCN}^{-}$by $\mathrm{H}_{2} \mathrm{O}_{2}$, Table S5: Effect of varying [LPO] on the rate of the pre-steady-state reaction for the LPO-catalyzed oxidation of $\mathrm{SCN}^{-}$by $\mathrm{H}_{2} \mathrm{O}_{2}$, Table S6: Fitted rate constants for the proposed mechanism of the LPO-catalyzed oxidation of $\mathrm{SCN}^{-}$by $\mathrm{H}_{2} \mathrm{O}_{2}$ as $\left[\mathrm{SCN}^{-}\right]$was varied, Table S7: Fitted rate constants for the proposed mechanism of the LPO-catalyzed oxidation of $\mathrm{SCN}^{-}$by $\mathrm{H}_{2} \mathrm{O}_{2}$ as $\left[\mathrm{H}_{2} \mathrm{O}_{2}\right]$ was varied, Table S8: Fitted rate constants for the proposed mechanism of the LPO-catalyzed oxidation of $\mathrm{SCN}^{-}$by $\mathrm{H}_{2} \mathrm{O}_{2}$ as [LPO] was varied.

Author Contributions: Both authors contributed equally to all aspects of this research. All authors have read and agreed to the published version of the manuscript.

Funding: This research was funded by the National Science Foundation grant number CHE-0911328.

Institutional Review Board Statement: Not applicable.

Informed Consent Statement: Not applicable.

Data Availability Statement: The data described in this study are available [42].

Acknowledgments: This article is dedicated to Jack Halpern, who taught MTA most of what he knows about mechanistic studies. The authors are also grateful to Paul F. Cook for valuable discussions.

Conflicts of Interest: The authors declare no conflict of interest.

\section{References}

1. Davies, M.J.; Hawkins, C.L.; Pattison, D.I.; Rees, M.D. Mammalian Heme Peroxidases: From Molecular Mechanisms to Health Implications. Antioxid. Redox Signal. 2008, 10, 1199-1234. [CrossRef]

2. Furtmuller, P.G.; Zederbauer, M.; Jantschko, W.; Helm, J.; Bogner, M.; Jakopitsch, C.; Obinger, C. Active site structure and catalytic mechanisms of human peroxidases. Arch. Biochem. Biophys. 2006, 445, 199-213. [CrossRef] [PubMed]

3. Furtmuller, P.G.; Jantschko, W.; Regelsberger, G.; Jakopitsch, C.; Arnhold, J.; Obinger, C. Reaction of lactoperoxidase compound I with halides and thiocyanate. Biochemistry 2002, 41, 11895-11900. [CrossRef] [PubMed]

4. Ashby, M.T. Inorganic chemistry of defensive peroxidases in the human oral cavity. J. Dent. Res. 2008, 87, 900-914. [CrossRef] [PubMed]

5. Ashby, M.T. Hypothiocyanite. Adv. Inorg. Chem. 2012, 64, 263-303. [CrossRef]

6. Alfonso-Prieto, M.; Borovik, A.; Carpena, X.; Murshudov, G.; Melik-Adamyan, W.; Fita, I.; Rovira, C.; Loewen, P.C. The Structures and Electronic Configuration of Compound I Intermediates of Helicobacter pylori and Penicillium vitale Catalases Determined by X-ray Crystallography and QM/MM Density Functional Theory Calculations. J. Am. Chem. Soc. 2007, 129, 4193-4205. [CrossRef]

7. Rovira, C. Structure, protonation state and dynamics of catalase compound II. ChemPhysChem 2005, 6, 1820-1826. [CrossRef]

8. Hersleth, H.P.; Dalhus, B.; Gorbitz, C.H.; Andersson, K.K. An iron hydroxide moiety in the $1.35 \AA$ resolution structure of hydrogen peroxide derived myoglobin compound II at pH 5.2. JBIC J. Biol. Inorg. Chem. 2002, 7, 299-304. [CrossRef]

9. Arnao, M.B.; Acosta, M.; Del Rio, J.A.; Varon, R.; Garcia-Canovas, F. A kinetic study on the suicide inactivation of peroxidase by hydrogen peroxide. Biochim. Biophys. Acta-Protein Struct. Mol. Enzymol. 1990, 1041, 43-47. [CrossRef]

10. Arnao, M.B.; Acosta, M.; Del Rio, J.A.; Garcia-Canovas, F. Inactivation of peroxidase by hydrogen peroxide and its protection by a reductant agent. Biochim. Biophys. Acta-Protein Struct. Mol. Enzymol. 1990, 1038, 85-89. [CrossRef]

11. Jenzer, H.; Kohler, H.; Broger, C. The role of hydroxyl radicals in irreversible inactivation of lactoperoxidase by excess hydrogen peroxide. A spin-trapping/ESR and absorption spectroscopy study. Arch. Biochem. Biophys. 1987, 258, 381-390. [CrossRef]

12. Jenzer, H.; Jones, W.; Kohler, H. On the molecular mechanism of lactoperoxidase-catalyzed hydrogen peroxide metabolism and irreversible enzyme inactivation. J. Biol. Chem. 1986, 261, 15550-15556. [CrossRef]

13. Huwiler, M.; Jenzer, H.; Kohler, H. The role of compound III in reversible and irreversible inactivation of lactoperoxidase. Eur. J. Biochem. 1986, 158, 609-614. [CrossRef]

14. Ghibaudi, E.; Laurenti, E.; Pacchiardo, C.; Suriano, G.; Moguilevsky, N.; Ferrari, R.P. Organic and inorganic substrates as probes for comparing native bovine lactoperoxidase and recombinant human myeloperoxidase. J. Inorg. Biochem. 2003, 94, 146-154. [CrossRef] 
15. Sheikh, I.A.; Singh, A.K.; Singh, N.; Sinha, M.; Singh, S.B.; Bhushan, A.; Kaur, P.; Srinivasan, A.; Sharma, S.; Singh, T.P. Structural evidence of substrate specificity in mammalian peroxidases: Structure of the thiocyanate complex with lactoperoxidase and its interactions at 2.4 A resolution. J. Biol. Chem. 2009, 284, 14849-14856. [CrossRef]

16. Ghibaudi, E.; Laurenti, E. Unraveling the catalytic mechanism of lactoperoxidase and myeloperoxidase: A reflection on some controversial features. Eur. J. Biochem. 2003, 270, 4403-4412. [CrossRef]

17. Gau, J.; Arnhold, J.; Flemmig, J.; Furtmuller, P.-G.; Obinger, C.; Arnhold, J.; Flemmig, J. Enhancing hypothiocyanite production by lactoperoxidase-mechanism and chemical properties of promotors. Biochem. Biophys. Rep. 2015, 4, 257-267. [CrossRef]

18. Fielding, A.J.; Singh, R.; Boscolo, B.; Loewen, P.C.; Ghibaudi, E.M.; Ivancich, A. Intramolecular Electron Transfer versus Substrate Oxidation in Lactoperoxidase: Investigation of Radical Intermediates by Stopped-Flow Absorption Spectrophotometry and (9-285 GHz) Electron Paramagnetic Resonance Spectroscopy. Biochemistry 2008, 47, 9781-9792. [CrossRef] [PubMed]

19. Jantschko, W.; Furtmuller, P.G.; Allegra, M.; Livrea, M.A.; Jakopitsch, C.; Regelsberger, G.; Obinger, C. Redox intermediates of plant and mammalian peroxidases: A comparative transient-kinetic study of their reactivity toward indole derivatives. Arch. Biochem. Biophys. 2002, 398, 12-22. [CrossRef] [PubMed]

20. Sharma, S.; Singh, A.K.; Kaushik, S.; Sinha, M.; Singh, R.P.; Sharma, P.; Sirohi, H.; Kaur, P.; Singh, T.P. Lactoperoxidase: Structural insights into the function, ligand binding and inhibition. Int. J. Biochem. Mol. Biol. 2013, 4, 108-128.

21. Edgcomb, S.P.; Murphy, K.P. Variability in the pKa of histidine side-chains correlates with burial within proteins. Proteins Struct. Funct. Genet. 2002, 49, 1-6. [CrossRef]

22. Bardsley, W.G. Steady-state kinetics of lactoperoxidase-catalyzed reactions. Immunol. Ser. 1985, $27,55-87$.

23. Ashby, M.T.; Kreth, J.; Soundarajan, M.; Sivuilu, L.S. Influence of a model human defensive peroxidase system on oral streptococcal antagonism. Microbiology 2009, 155, 3691-3700. [CrossRef]

24. Xu, Y.; Szep, S.; Lu, Z. The antioxidant role of thiocyanate in the pathogenesis of cystic fibrosis and other inflammation-related diseases. Proc. Natl. Acad. Sci. USA 2009, 106, 20515-20519. [CrossRef]

25. Al-Shehri, S.S.; Knox, C.L.; Liley, H.G.; Cowley, D.M.; Wright, J.R.; Henman, M.G.; Hewavitharana, A.K.; Charles, B.G.; Shaw, P.N.; Sweeney, E.L.; et al. Breastmilk-saliva interactions boost innate immunity by regulating the oral microbiome in early infancy. PLoS ONE 2015, 10, e0135047. [CrossRef] [PubMed]

26. Fragoso, M.A.; Fernandez, V.; Forteza, R.; Randell, S.H.; Salathe, M.; Conner, G.E. Transcellular thiocyanate transport by human airway epithelia. J. Physiol. 2004, 561, 183-194. [CrossRef] [PubMed]

27. Tsuge, K.; Kataoka, M.; Seto, Y. Cyanide and thiocyanate levels in blood and saliva of healthy adult volunteers. J. Health Sci. 2000, 46, 343-350. [CrossRef]

28. Conner, G.E.; Wijkstrom-Frei, C.; Randell, S.H.; Fernandez, V.E.; Salathe, M. The lactoperoxidase system links anion transport to host defense in cystic fibrosis. FEBS Lett. 2007, 581, 271-278. [CrossRef] [PubMed]

29. Moskwa, P.; Lorentzen, D.; Excoffon, K.J.D.A.; Zabner, J.; McCray, P.B., Jr.; Nauseef, W.M.; Dupuy, C.; Banfi, B. A novel host defense system of airways is defective in cystic fibrosis. Am. J. Respir. Crit. Care Med. 2007, 175, 174-183. [CrossRef] [PubMed]

30. Kalmar, J.; Woldegiorgis, K.L.; Biri, B.; Ashby, M.T. Mechanism of Decomposition of the Human Defense Factor Hypothiocyanite Near Physiological pH. J. Am. Chem. Soc. 2011, 133, 19911-19921. [CrossRef]

31. Halliwell, B.; Clement, M.V.; Long, L.H. Hydrogen peroxide in the human body. FEBS Lett. 2000, 486, 10-13. [CrossRef]

32. Thomas, E.L.; Pera, K.A.; Smith, K.W.; Chwang, A.K. Inhibition of Streptococcus mutans by the lactoperoxidase antimicrobial system. Infect. Immun. 1983, 39, 767-778. [CrossRef] [PubMed]

33. Mattana, A.; Juliano, C.; Bennardini, F.; Mignano, M.; Marceddu, S.; Picci, V.; Di Simplicio, P.; Franconi, F. Hydrogen peroxideinduced cytotoxicity in cultured epithelial cells (WISH): A functional and morphological study. Toxicol. Vitr. 1992, 6, 533-541. [CrossRef]

34. Tenovuo, J.; Larjava, H. The protective effect of peroxidase and thiocyanate against hydrogen peroxide toxicity assessed by the uptake of [3H]-thymidine by human gingival fibroblasts cultured in vitro. Arch. Oral Biol. 1984, 29, 445-451. [CrossRef]

35. Tipton, D.A.; Braxton, S.D.; Dabbous, M.K. Effects of a bleaching agent on human gingival fibroblasts. J. Periodontol. 1995, 66, 7-13. [CrossRef]

36. Haenstroem, L.; Johansson, A.; Carlsson, J. Lactoperoxidase and thiocyanate protect cultured mammalian cells against hydrogen peroxide toxicity. Med. Biol. 1983, 61, 268-274.

37. White, W.E., Jr.; Pruitt, K.M.; Mansson-Rahemtulla, B. Peroxidase-thiocyanate-peroxide antibacterial system does not damage DNA. Antimicrob. Agents Chemother. 1983, 23, 267-272. [CrossRef] [PubMed]

38. Carlsson, J.; Edlund, M.B.; Haenstroem, L. Bactericidal and cytotoxic effects of hypothiocyanite-hydrogen peroxide mixtures. Infect. Immun. 1984, 44, 581-586. [CrossRef]

39. Carlsson, J. Salivary peroxidase: An important part of our defense against oxygen toxicity. J. Oral Pathol. 1987, 16, 412-416. [CrossRef]

40. Tipton, D.A.; Braxton, S.D.; Dabbous, M.K. Role of saliva and salivary components as modulators of bleaching agent toxicity to human gingival fibroblasts in vitro. J. Periodontol. 1995, 66, 766-774. [CrossRef] [PubMed]

41. Vlasits, J.; Jakopitsch, C.; Bernroitner, M.; Zamocky, M.; Furtmueller, P.G.; Obinger, C. Mechanisms of catalase activity of heme peroxidases. Arch. Biochem. Biophys. 2010, 500, 74-81. [CrossRef] [PubMed]

42. Cupp-Sutton, K. A Study of Hyposelenocyanite and the Kinetics and Mechanism of the Lactoperoxidase System. Available online: https:/ / shareok.org/bitstream/handle/11244/316797/2018_Cupp-Sutton_Kellye_Dissertation.pdf?sequence=2 (accessed on 15 October 2021). 